\title{
Combination of Organic and Plastic Mulches to Improve the Yield and Quality of Winter Fresh Market Bell Peppers (Capsicum annuum L.)
}

\author{
Qingren Wang1, Waldemar Klassen, Edward A. Evans, Yungcong Li, \\ and Merlyn Codallo \\ Tropical Research and Education Center, University of Florida, 18905 SW \\ 280th Street, Homestead, FL 33031
}

Additional index words. Bell pepper, compost, fumigation, herbicide, methyl bromide, organic mulch, plastic mulch

\begin{abstract}
Mulching in vegetable cultivation has been widely used to conserve water and improve yield. Field experiments with four treatments, including yard waste compost combined with plastic mulches in raised beds for winter fresh market bell peppers (Capsicum annuum L.), were conducted at two experimental sites [Pine Island Farm (PIF) and Tropical Research and Education Center (TREC)] in Miami-Dade county for two different years each. The treatments were: 1) control (PM): plastic mulch alone; 2) MC33: fumigation of the soil with a mixture of methyl bromide and chloropicrin and covered with plastic mulch; 3) herbicide/OM: organic mulch sprayed with herbicides (S-metolachlor and napropamide) without plastic mulch; and 4) PM/OM: organic mulch covered by plastic mulch. The treatment of $\mathrm{PM} / \mathrm{OM}$ at both experimental sites in 2 years each increased the total marketable yields of bell pepper by 1.5- to 3.2-fold, total extra large fruit yields by 2.0- to 5.7-fold, and total large fruit yields by 1.4- to 2.6-fold, respectively, on average compared with the control, although some exceptions occurred between the two years at the TREC site. Under most circumstances at both experimental sites in two different years each, the $\mathrm{PM} / \mathrm{OM}$ treatment also improved the total marketable yield and fruit quality (such as extra large fruits) for the first two harvests, which shows a preference to provide winter fresh market vegetables to meet a high demand. The economic benefit by $\mathrm{PM} / \mathrm{OM}$ was the greatest among all the treatments. The results suggest that the application of organic mulch combined with plastic mulch can improve bell pepper yield and quality as a result of the improvement of soil fertility, especially the early harvests of winter fresh market fruits, which has shown a potential in the development of sustainable agriculture.
\end{abstract}

Production of fresh market vegetables in winter is an important industry in a tropical or subtropical region such as south Florida. Vegetables in this region are mainly grown either in very sandy or gravelly loam soil developed from limestone bedrocks with low soil fertility. The nutrients in these soils are prone to leaching through the coarse-textured soil profiles by heavy rainfall events that occur mainly during the rainy summer season. On average, more than $1000 \mathrm{~mm}$ of rain happens between June and October in this region (Wang et al., 2002). Such a heavy

\footnotetext{
Received for publication 30 Nov. 2009. Accepted for publication 1 Mar. 2010.

We are deeply grateful to the Cooperative State Research Service, USDA, for funding support through Special Grant 2006-34136-16940 and to the late Jack Wishart, Lynn Chafin, and Robert Castillo for exceedingly helpful and generous support in conducting the research at Pine Island Farms. In addition, we are grateful to Robert Stubblefield, Jose Castillo, Jacob Hall, Bill Smith, and Keith McCrow of the field crew at the Tropical Research and Education Center for invaluable assistance.

${ }^{1}$ To whom reprint requests should be addressed; e-mail qrwang@ufl.edu.
}

rainfall may cause intensive loss of leached fertilizers from farmland. As a consequence, the nutrient loss may lead to surface water eutrophication and threaten the adjacent natural ecosystems such as the Florida Everglades and Florida Bay (South Florida Water Management District, 2007). Therefore, it is important to develop a sustainable cropping system to improve agricultural production and the environment by effectively conserving soil and water in such a fragile region.

Composts of municipal solid wastes, including yard wastes, paper, cardboard, food waste, textiles, and so on, have shown high potential to improve soil fertility and production of various crops. For instance, the application of composts can significantly improve the yields of various vegetable crops, including tomato (Lycopersicon esculentum), bell pepper, broccoli (Brassica oleracea), sweet corn (Zea mays), eggplant (Solanum melongena), okra (Abelmoschus esculentus), cucumber (Cucumis sativus), snap bean (Phaseolus vulgaris), squash (Cucurbita moschata), and watermelon (Citrullus lanatus) (Maynard, 1995; Ozores-Hampton, et al., 1994; Wang et al., 2006, 2007). Composts have been recommended and authorized by the U.S. Environmental
Protection Agency (U.S. EPA, 1994) and by the Florida Department of Environmental Protection (Goldstein, 1997) as a partial substitute for inorganic fertilizers in the production of these vegetable crops. Compost production is a growing industry because of population growth. In the state of Florida, $\approx 3.7 \times 10^{7} \mathrm{Mg}$ of municipal solid wastes (MSW) is collected per year, which includes $4 \times 10^{6} \mathrm{Mg}$ of yard waste, but only $37 \%$ of the yard waste is recycled (Florida Department of Environmental Protection, 2007). According to the U.S. EPA (1994), $30 \%$ to $60 \%$ of a community's MSW can be processed into compost. The U.S. agricultural industry is the largest consumer of compost and has the potential to consume 800 million $\mathrm{m}^{3}$ of compost per year. Such capacity is more than 10-fold the amount of MSW compost generated by the entire United States (Slivka et al., 1992; U.S. EPA, 1993). Soil incorporation of compost usually causes rapid mineralization of organic matter through microbial activities (Cambardella et al., 2003).

The benefits to agricultural soils from compost include increases in soil organic matter (Cortellini et al., 1996; Maynard, 1995), soil cation exchange capacity (Paino et al., 1996), soil water-holding capacity (Serria-Wittling et al., 1996; Turner et al., 1994), $\mathrm{pH}$ of acidic soils, soil microbial and enzymatic activity (Rothwell and Hortenstine, 1969), and reductions in soil bulk density (Turner et al., 1994). Because composts applied as an organic mulch on the soil surface are decomposed much more slowly than those incorporated into the soil, they can serve as a season-long mulch. They can also improve the water-holding capacity and reduce the bulk density of the soil in the upper part of the root zone (Wang et al., 2009).

Yield responses to the application of composts incorporated into the soil vary among crop species and with the quality of the compost. In most cases, crop yields respond positively to compost application (Stoffella and $\mathrm{Li}, 2001$ ). The yields of snap bean and tomato increased by $22 \%$ and $38 \%$, respectively, in response to incorporation of MSW compost (Maynard, 1995). However, under some circumstances, yield loss has been observed with compost-induced nitrogen $(\mathrm{N})$ deficiency and phytotoxicity in peppers (Clark et al., 1995). Such phytotoxicity is considered to be caused mainly by compost immaturity with a high $\mathrm{C}: \mathrm{N}$ ratio. High $\mathrm{C}: \mathrm{N}$ ratio usually causes the immobilization of soil mineral $\mathrm{N}$ through competition between soil microorganisms and plants for the limited quantity of available N. $\mathrm{N}$ immobilization usually occurs when the soil microbial population draws $\mathrm{N}$ mostly from the soil inorganic pool rather than from decomposing soil organic matter and thereby induces crop N deficiency (Beloso et al., 1993; Duggan, 1973; Wang et al., 2007).

In addition to improving crop yields, some composts can suppress soilborne nematodes and plant pathogens (Bryan et al., 1997; Chellemi et al., 1992; Mannion et al., 1994; Wang et al., 2007). Such nematodes, particularly root-knot nematodes, and pathogens are a major concern in vegetable production, especially in tropical or subtropical regions 
where pest populations thrive year-round. Thus, the application of certain composts may serve as partial alternatives to soil fumigants to suppress weeds in vegetable production systems (Li et al., 2000; Stoffella and Li, 2001). The objectives of this research were to evaluate treatments, including the application of compost as an organic mulch with and without plastic mulch, soil fumigation with methyl bromide-chloropicrin, and use of herbicides, to study the following effects: 1) yield and quality responses of bell peppers; 2) the impact on soil fertility; and 3) the economic benefits in winter fresh market bell pepper production.

\section{Materials and Methods}

Experimental sites and primary conditions. Two field experimental sites were selected; one at Pine Island Farms (PIF) in western Kendall, FL (long. $25^{\circ} 39^{\prime} 5^{\prime \prime} \mathrm{N}$, lat. 80 $24^{\prime} 46^{\prime \prime}$ W) and the other at the Tropical Research and Education Center (TREC), University of Florida, Homestead, FL (long. $25^{\circ} 30^{\prime} 41^{\prime \prime} \mathrm{N}$, lat. $\left.80^{\circ} 30^{\prime} 08^{\prime \prime} \mathrm{W}\right)$, respectively. In this region, the average annual rainfall is $1499 \mathrm{~mm}$, of which an average of $76 \%$ falls between the beginning of June and the beginning of October. The annual temperature in average is $23.9^{\circ} \mathrm{C}$ and it ranges from a monthly average maximum of $35{ }^{\circ} \mathrm{C}$ in August to a monthly average minimum of $5{ }^{\circ} \mathrm{C}$ in January (Wang et al., 2002).

The site at PIF had been used each year for the past decade for commercial winter fresh market vegetable production, and the last crop of tomato had been grown from October through March. The site at the TREC had been used for experiments on culturing raspberry and okra and had been kept fallow for 6 months preceding this experiment. On both sites each year, a conventional summer cover crop, sorghum sudangrass [Sorghum bicolor $\times S$. bicolor var. sudanense (Piper) Stapf.], seeded at $45 \mathrm{~kg} \cdot \mathrm{ha}^{-1}$, was grown from June through August, flail mowed, and the biomass was incorporated into the soil as green manure. The amounts of cover crop biomass produced across the 4 years at the two locations varied from 3.0 to $5.0 \mathrm{Mg} \cdot \mathrm{ha}^{-1}$. The soil at PIF was Dade sandy loam (hyperthermic, uncoated Spodic Quartzipsamments), and the soil at TREC was Krome very gravelly loam (loamy-skeletal, carbonatic, hyperthermic Lithic Udorthents). The Dade sandy loam mainly consists of silt and fine sand with a particle distribution of $45.6 \%$ sand, $47.8 \%$ silt, and $6.6 \%$ clay. The Krome very gravelly loam contains $58.8 \%$ gravel (greater than $2 \mathrm{~mm}$ ) and has a distribution of soil particles in the nongravel fraction of
$48.4 \%$ sand, $30.3 \%$ silt, and $21.3 \%$ clay. Both soils on these two locations are shallow and underlain by oolitic limestone and they have low soil fertility with a soil $\mathrm{pH}$ of 7.5 to 7.9. Selected characteristics of these soils and the compost are summarized in Table 1.

Experimental design and management. A randomized complete block design with four treatments was used in each growing season at both sites. The experiments were conducted in four annual pepper growing seasons at PIF (2004 through 2006) and TREC (2006 to 2008) sites with four replicates for each treatment. Four weeks after the cover crop residues were applied to the soil, the land was disked twice. The raised beds were formed each $91 \mathrm{~cm}$ wide and $15 \mathrm{~cm}$ high, and there was 91-cm separation between adjacent beds as a conventional practice in the region. Each plot was $20 \mathrm{~m}$ long and $0.9 \mathrm{~m}$ wide with $0.9 \mathrm{~m}$ on each side of the plot as a margin. The experimental treatments were: 1) control (PM): raised beds covered by plastic mulch alone; 2) MC33: fumigated the soil with a mixture of methyl bromide $(67 \%)$ and chloropicrin (33\%) and covered with plastic mulch; 3 ) herbicides/OM: compost applied as an organic mulch, and the herbicides S-metolachlor (Dual Magnum ${ }^{\circledR}$; Syngenta Crop Protection, Wilmington, DE) and napropamide (Devrinol®; Syngenta Crop Protection) applied in a tank mix to the organic mulch with no plastic mulch; and 4) PM/OM: plastic mulch covered organic mulch of compost applied to the raised beds. The International Union of Pure and Applied Chemistry names for S-metolachlor and napropamide are $80 \%$ to $100 \%$ 2-chloro-N-(6-ethyl-o-tolyl)-N-[(1S)2-methoxy-1-methylethyl]acetamide and $0 \%$ to $20 \%$ 2-chloro-N-(6-ethyl-o-tolyl)-N-[(1R)2-methoxy-1-methylethyl] acetamide, and (RS)-N,N-diethyl-2-(1-naphthyloxy) propionamide, respectively.

In all treatments, dry fertilizer formulated as $6 \mathrm{~N}-6 \mathrm{P}_{2} \mathrm{O}_{5}-12 \mathrm{~K}_{2} \mathrm{O}$ at $670 \mathrm{~kg} \cdot \mathrm{ha}^{-1}$ was banded $25 \mathrm{~cm}$ from each side of the bed center and rototilled into the soil and the beds were reformed. Yard waste compost (All Grow Compost, produced by the Palm Beach Solid Waste Authority and delivered by SynagroWWT, Inc., Bartow, FL) at $50 \mathrm{Mg} \cdot \mathrm{ha}^{-1}$ dry weight equivalent was spread evenly on surfaces of the respective beds. The herbicides, S-metolachlor (1.78 L $\cdot \mathrm{ha}^{-1}$ with a.i. $83 \%$ ) and napropamide (4.5 $\mathrm{kg} \cdot \mathrm{ha}^{-1}$ with a.i. $43 \%$ ) as a tank mix were sprayed on surfaces of those beds for the treatment of herbicides/PM. Likewise, MC33, a mixture of methyl bromide $(67 \%)$ and chloropicrin (33\%) at $205 \mathrm{~kg} \cdot \mathrm{ha}^{-1}$, was injected into the soil using liquid $\mathrm{N}$ as the propellant and the treated beds were immedi- ately covered with plastic mulch (Canslit ${ }^{\mathrm{TM}}$ metalized; Intergro Inc., Clearwater, FL). Two parallel drip lines (T-TAPE TSX 508-12-450 with flow rate of $5.6 \mathrm{~L} \cdot \mathrm{min}^{-1}$ per $100 \mathrm{~m}$ with drip spacing $30 \mathrm{~cm}$ and diameter $16 \mathrm{~mm}$; Agro Distributors, Homestead, FL) $35 \mathrm{~cm}$ apart were installed on the surface of each bed and covered with the same plastic mulch as in the MC33 treatment for the respective treatments. The drip tapes were left on top of the organic mulch and fastened with stakes to prevent wind from displacing these drip lines for the treatment without plastic mulch. A mixture of S-metolachlor and metrabuzin in the same rate as previously were sprayed onto the soil surface in the aisles to suppress weeds.

In plots with plastic mulch treatments, holes were made through the plastic mulch for transplanting after $14 \mathrm{~d}$ of methyl bromide applied as the MC33 treatment. Bell pepper (Capsicum annuum, cv. Cascade) seedlings were transplanted between October and November in two rows per bed separated by $40 \mathrm{~cm}$ with an in-row interplant spacing of $30 \mathrm{~cm}$. Liquid fertilizer formulated (percentage) as $4 \mathrm{~N}-0 \mathrm{P}_{2} \mathrm{O}_{5}-8 \mathrm{~K}_{2} \mathrm{O}$ was injected through the drip lines twice a week initially at 1.2 $\mathrm{kg} \cdot \mathrm{ha}^{-1}$ of $\mathrm{N}$ per day and then at $1.8 \mathrm{~kg} \cdot \mathrm{ha}^{-1}$ of $\mathrm{N}$ per day at the onset of flowering until the last harvest. The bell pepper plants were irrigated at the same rate for every plot based on tensiometer readings with soil moisture maintained between $\approx-10 \mathrm{kPa}$ and $-25 \mathrm{kPa}$ in plots with and without plastic mulch. During the growing season, tank mixes of insecticide [Admire ${ }^{\circledR}$, imidacloprid, (E)-1-(6-chloro-3pyridylmethyl)-N-nitroimidazolidin-2-ylideneamine] with a.i. $21.4 \%$ and fungicide [Kocide ${ }^{\circledR}$, copper (II) hydroxide (DuPont Crop Protection Co. Inc, Wilmington, DE)] with a.i. $77.0 \%$ at a rate of 2 to $4 \mathrm{~kg} \cdot \mathrm{ha}^{-1}$ were sprayed twice a week onto the pepper plants to control various insects and mite pests and fungal and bacterial diseases (Olson et al., 2006). In 2008, severe outbreaks of the pepper weevil (Anthonomus eugenii Cano) were brought under control with thiamethoxam $\left[\right.$ Actara ${ }^{\circledR},(E Z)-3$-(2-chloro-1,3thiazol-5-ylmethyl)-5-methyl-1,3,5-oxadiazinan4-ylidene (nitro) amine with a.i. 25\% (Syngenta Crop Protection)] and sodium aluminofluoride [Prokill ${ }^{\circledR}$ Cryolite 50 Dust, aluminum trisodium hexafluoride with a.i. 50\% (Gowan Company, Yuma, AZ)] at a rate of $30 \mathrm{~kg} \cdot \mathrm{ha}^{-1}$. The weevil pest was not troublesome in the three prior growing seasons.

The peppers were harvested from four to seven times based on plant growth status and a potential to produce marketable fruits. The first harvest usually started at the end of December. To avoid a cross effect of various treatments, all harvests were conducted from

Table 1. Primary characteristics of the sandy soil at PIF site, of the Krome gravelly loam at TREC site, and of the compost applied as an organic mulch.

\begin{tabular}{|c|c|c|c|c|c|c|c|c|}
\hline & $\begin{array}{l}\text { Organic carbon } \\
\qquad\left(\mathrm{g} \cdot \mathrm{kg}^{-1}\right)\end{array}$ & $\begin{array}{l}\text { Inorganic carbon } \\
\qquad\left(\mathrm{g} \cdot \mathrm{kg}^{-1}\right)\end{array}$ & $\begin{array}{c}\mathrm{pH}^{\mathrm{z}} \\
\text { (water) }\end{array}$ & $\begin{array}{c}\mathrm{EC} \\
\left(\mathrm{mS} \cdot \mathrm{cm}^{-1}\right)\end{array}$ & $\begin{array}{l}\text { Total nitrogen } \\
\left(\mathrm{g} \cdot \mathrm{kg}^{-1}\right)\end{array}$ & $\begin{array}{l}\text { Total phosphorus } \\
\left(\mathrm{g} \cdot \mathrm{kg}^{-1}\right)\end{array}$ & $\begin{array}{c}\mathrm{NH}_{4}-\mathrm{N} \\
\left(\mathrm{mg} \cdot \mathrm{kg}^{-1}\right)\end{array}$ & $\begin{array}{c}\mathrm{NO}_{3}-\mathrm{N} \\
\left(\mathrm{mg} \cdot \mathrm{kg}^{-1}\right)\end{array}$ \\
\hline Sandy soil & 11.0 & 10.5 & 7.46 & 0.40 & 0.96 & 0.42 & 2.34 & 35.15 \\
\hline Gravelly soil & 23.2 & 63.1 & 7.85 & 0.23 & 1.26 & 1.13 & 2.58 & 12.40 \\
\hline Compost & 173.8 & 22.4 & 7.72 & 1.70 & 2.01 & 0.73 & 5.88 & 29.0 \\
\hline
\end{tabular}

'Soil:water ratio $=1: 2.5$.

$\mathrm{EC}=$ electrical conductivity. 
the middle of each plot with an 8-m length to each end. At each harvest, the fruits were separated into extra large and large fruits and for the last few harvests, medium-sized fruits and culls were recorded according to U.S. Standards for Grades of Sweet Peppers [U.S. Department of Agriculture (USDA), 1989].

Sampling and chemical analysis. Soil samples were collected at a depth of 0 to $20 \mathrm{~cm}$ before and after the experiments. The samples were air-dried, ground, and passed through 2-mm diameter sieve for chemical analyses. Soil total carbon (C) and total $\mathrm{N}$ were analyzed with a $\mathrm{CN}$ Auto-analyzer (Vario Max Elementar, Hanau, Germany). Soil organic carbon was determined by the weight loss on ignition method (Heiri et al., 2001). The soil inorganic $\mathrm{C}$ contents were determined by the pressure-calcimeter method calibrated with reagent-grade $\mathrm{CaCO}_{3}$ (Wagner et al., 1998). To determine the total phosphorus, soil samples were digested with concentrated nitric acid-hydrogen peroxide-hydrochloric acid $\left(\mathrm{HNO}_{3}-\mathrm{H}_{2} \mathrm{O}_{2}-\mathrm{HCl}\right)$ according to the U.S. EPA method, 3050A (U.S. EPA, 1990) and then analyzed by inductively coupled plasma optical emission spectroscopy (Ultima 2C, Horiba Jobin Yvon Inc., Edison, NJ).

Statistical analysis. The data were subjected to analysis of variance (ANOVA) with a general linear model for each individual site with 2-year experiments each for the same treatments. Duncan's multiple range tests were adopted to separate the means of each fruit yield category for a significant difference at $P<0.05$ by means of the SAS program for each experimental site (Version 9.1.3; SAS Institute, 2004).

Economic analysis and assumptions. Each of the four management practices was treated as a separate enterprise and estimated net returns, defined as the difference between gross returns and total costs, were used to compare the profitability of each practice. Annual enterprise budgets were assembled based on the field data collected over the 2year period and modification of a recent budget for the MC33 system published by Smith (2004). The information was supplemented with estimates of prices and other technical coefficients where appropriate. Primary field data collected at the research sites include treatment-level quantities of material inputs applied, time required and number of field operations performed, and crop yield and quality. Supplementary secondary data required for estimating cropping system costs and returns include prices paid for inputs, including materials, transportation, labor, and commodity prices. Because the focus of the experiment revolved around assessing different management practices, fixed costs such as facility depreciation, wear, taxes, land rent, housing, and insurance were assumed to be the same. Hence, the assessment of the profit reflected changes in variable costs associated with each management practice and differences in yield and quality.

Two of the production systems required the procurement and transportation of yard waste compost. High-quality compost is available commercially at $\approx \$ 13.23 / \mathrm{Mg}$, which is the price used in this analysis. Given that it requires $25 \mathrm{Mg} \cdot \mathrm{ha}^{-1}$ of compost to achieve a rate of $50 \mathrm{Mg} \cdot \mathrm{ha}^{-1}$ on the raised beds, the material cost of this input was estimated at \$331/ha. In 2007, the cost of operating a truck, which could carry $25 \mathrm{Mg}$, was $\$ 4$ per mile round trip with a total transportation distance of 200 miles. Thus, we estimated the cost of hauling $25 \mathrm{Mg}$ at $\$ 800$. To estimate the cost of spreading the compost, the hourly operating cost of the tractor and spreader was $\$ 10 / \mathrm{h}$ and the pay for the driver $\$ 15 / \mathrm{h}$ for at total of $\$ 25 / \mathrm{h}$. Compost could be loaded into the spreader and distributed on the raised beds in $4.0 \mathrm{~h} \cdot \mathrm{ha}^{-1}$. Thus, the material cost, acquisition, hauling, and spreading of the compost was estimated to have a cost of $\$ 1231 /$ ha.

Because market prices and yields were somewhat uncertain and costs of these four treatments in the study differed, it is essential for growers to know the minimum benefit needed to cover both the fixed and variable costs of production and marketing. The breakeven price and yield were chosen as a criterion to assess the economic benefit. Breakeven yield was calculated by dividing total costs (fixed and total variable costs) for the enterprise by the average market price. Likewise, the breakeven price was calculated by dividing the total cost (fixed and variable costs) by the average yield (Beirlein et al., 1995):

$$
\text { Breakeven yield }
$$

$=\frac{\text { Fixed Costs }+ \text { Total Variable Cost }}{\text { Average Market Price }}$

$$
\text { Breakeven price }=\frac{\text { Total Costs }}{\text { Average Yield }}
$$

Moreover, to overcome the year-to-year variations in both yields and prices, given the vagaries of weather and markets, a margin of safety was defined as the difference between the expected market price and the breakeven price expressed as a percentage of the breakeven price. The margin safety was calculated and used as a criterion to also evaluate the overall benefits from different treatments. The margin of safety implies the extent to which either price or yield could fall before the operation becomes nonprofitable. For this study based on discussions with growers, it was assumed that a risk-averse grower would unlikely adopt a production system if a margin of safety is less than $20 \%$. Margin safety was calculated as follows:

$$
\begin{aligned}
& \text { Margin safety } \\
& \text { Estimated market price- } \\
& =\frac{\text { Breakeven price }}{\text { Breakeven price }} \times 100
\end{aligned}
$$

\section{Results and Discussion}

Variation of years, locations, and treatments for pepper yields and quality. Results from the ANOVA showed that the total marketable fruit yield and, large and extra large size fruit yields were significantly different among the treatments and between the two experimental years at each site (Table 2 ). However, there was no any interaction effect for year $\times$ treatment observed for either the total marketable or large or extra large fruit yields at both sites.

Further analysis showed that (Table 3) at the PIF site, the treatment of PM/OM produced significantly greater yields of the total marketable, extra large, and large fruit as compared with the control (PM) and MC33 and also herbicide/OM for the large fruit in 2004-2005. In 2005-2006 at PIF, similar yields of total marketable and large fruit were produced by the treatments of $\mathrm{PM} / \mathrm{OM}$ and MC33. The total marketable yields and large fruit yields were significantly greater than those of the control and herbicide/OM, but the greatest yield of extra large fruits was produced by the treatment of PM/OM. However, at the TREC site, the total marketable yield with $\mathrm{PM} / \mathrm{OM}$ was greater than that in the control in 2006-2007 but it was greater than that of herbicide/OM in 2007-2008. Regarding fruit quality, $\mathrm{PM} / \mathrm{OM}$ treatment had the greatest yield of extra large fruits in 2006-2007 and also the greatest yield of large fruits in 2007-2008. In addition, the $\mathrm{PM} / \mathrm{OM}$ treatment produced greater extra large fruit yield than the herbicide/OM treatment in 2007-2008, but the larger fruit yield

\begin{tabular}{|c|c|c|c|c|}
\hline \multirow[b]{2}{*}{ Source } & \multirow[b]{2}{*}{$\mathrm{df}^{2}$} & \multicolumn{3}{|c|}{$F$ value } \\
\hline & & Total marketable fruit yields & Extra large fruits & Large fruits \\
\hline \multicolumn{5}{|l|}{$\overline{\text { PIF } \text { site }^{\mathrm{y}}}$} \\
\hline Year & 1 & $59.04 * * *$ & $36.19 * * *$ & $26.68 * * *$ \\
\hline Treatment & 3 & $20.19 * * *$ & $18.93 * * *$ & $6.81 * *$ \\
\hline Year $\times$ treatment & 3 & 3.74 NS & $2.69 \mathrm{NS}$ & $1.18 \mathrm{NS}$ \\
\hline \multicolumn{5}{|l|}{ TREC site } \\
\hline Year & 1 & $5.22 * *$ & $6.75 *$ & $44.32 * * *$ \\
\hline Treatment & 3 & $7.19 * *$ & $7.26 * *$ & $5.69 * *$ \\
\hline Year $\times$ treatment & 3 & $2.32 \mathrm{NS}$ & $2.02 \mathrm{NS}$ & $1.41 \mathrm{NS}$ \\
\hline
\end{tabular}
than the control in 2006-2007 (Table 3). The yield responses at the PIF site displayed an

Table 2. Analysis of variance (ANOVA) of yields of extra large, large, and total marketable bell pepper fruit with different treatments in 2 years at two experimental sites.

${ }^{\mathrm{z}}$ Degrees of freedom.

${ }^{\mathrm{y}} \mathrm{PIF}=$ Pine Island Farm, Kendall, FL; TREC $=$ Tropical Research and Education Center, Homestead, FL. *Significant at $P \leq 0.05$; **significant at $P \leq 0.01$; ***significant at $P \leq 0.001$; NS $=$ nonsignificant difference at $P \leq 0.05$. 
advantage for the combination of organic much with plastic mulch as compared with PM alone, but such a trend was not that clear at the TREC site, which must be related to some other unexpected factors.

At the TREC site, substantial yield losses occurred in 2007-2008 because of failure to prevent outbreaks of the pepper weevil and soft rot, which were not as prevalent as in the previous season. The extensive damage by pepper weevil infestations and soft rot resulted in a large yield variation among replicates and might be one major reason for a blurred yield response. In addition, the effect of compost application on the pepper marketable yield seemed more substantial in the poor sandy soil at PIF rather than that in the relatively fertile gravelly loam soil at TREC. Also, the treatment of MC33 displayed some positive impacts on pepper yields under certain circumstances (Table 3). Such impacts might be attributed to an effective control of soil pests, weeds, and some pathogens such as the root-knot nematode, Meloidogyne incognita [Kofoid and White (Chitwood)], plant pathogens, phytophthora blight (Phytophthora capsici), collar and root rot (Rhizoctonia solani), fusarium wilt (Fusarium oxysporum $f$. sp. capsici and $F$. solani), and verticillium wilt (Verticillium dahliae and V. albo-atrum), and field weeds, yellow nutsedge (Cyperus esculentus L.), purple nutsedge (Cyperus rotundus L.), and various broadleaf weeds (U.S. Department of State, 2006). These soil pests, weeds, and pathogens were more prevalent in the sandy loam soil such as at the PIF than the Krome gravely loam. However, using compost alone to control soil pests and pathogens has shown a critical challenge in this region as a result of the favorable climate for the development and reproduction of such pests and pathogens. Although the effectiveness of methyl bromide, suppressing such pests, weeds, and pathogens were out of the focus in the current study the application of methyl bromide has been approved to influence the growth and production of vegetables in this region under a favorable climate.

In addition, the overall increases of the total marketable and extra large fruits with the second experimental year as compared with the first one (Table 3) might be attributed to soil fertility improvement because the same plots with the same treatments were used every year. A carryover effect from the previous year might be a considerable factor resulting in a higher yield in the next year. Even in the control plot, fertilization during the growth season and remaining crop residues after bell pepper fruits were harvested might contribute some carryover for the next season. Furthermore, sorghum sudangrass was grown as a cover crop in every plot after the final bell pepper harvest and mineralization on nutrients from the cover crop biomass might lead to a buildup in soil fertility. Nevertheless, the year impact seems especially important for the treatments with composts as organic mulches. The decomposition of such composts on the soil surface is obviously slow as a result of less contact

Table 3. Influence of treatments on total marketable yields $\left(\mathrm{Mg} \cdot \mathrm{ha}^{-1}\right)$ of bell pepper fruits in 2 years at two different sites.

\begin{tabular}{|c|c|c|c|c|}
\hline \multirow[b]{2}{*}{ Treatment $^{2}$} & \multicolumn{2}{|c|}{ PIF site ${ }^{y}$} & \multicolumn{2}{|c|}{ TREC site } \\
\hline & 2004-2005 & $2005-2006$ & 2006-2007 & $2007-2008$ \\
\hline & \multicolumn{4}{|c|}{ Total marketable yield $\left(M g \cdot h a^{-1}\right)$} \\
\hline Control (PM) & $5.19 \mathrm{~b}^{\mathrm{x}}$ & $6.47 \mathrm{~b}$ & $16.44 \mathrm{~b}$ & $17.18 \mathrm{ab}$ \\
\hline MC33 & $6.23 \mathrm{~b}$ & $17.08 \mathrm{a}$ & $21.53 \mathrm{ab}$ & $17.89 \mathrm{ab}$ \\
\hline Herbicide/OM & $12.96 \mathrm{a}$ & $10.44 \mathrm{~b}$ & $19.96 \mathrm{ab}$ & $14.14 \mathrm{~b}$ \\
\hline \multirow[t]{2}{*}{$\mathrm{PM} / \mathrm{OM}$} & $16.82 \mathrm{a}$ & $20.04 \mathrm{a}$ & $25.28 \mathrm{a}$ & $27.51 \mathrm{a}$ \\
\hline & \multicolumn{4}{|c|}{ Extra large fruit yield $\left(M g \cdot h a^{-1}\right)$} \\
\hline Control (PM) & $1.28 \mathrm{bc}$ & $2.45 \mathrm{c}$ & $5.52 \mathrm{~b}$ & $10.66 \mathrm{ab}$ \\
\hline MC33 & $3.06 \mathrm{~b}$ & $7.87 \mathrm{~b}$ & $6.50 \mathrm{~b}$ & $9.77 \mathrm{ab}$ \\
\hline Herbicide/OM & $5.21 \mathrm{ab}$ & $3.85 \mathrm{c}$ & $6.79 \mathrm{~b}$ & $6.49 \mathrm{~b}$ \\
\hline \multirow[t]{2}{*}{$\mathrm{PM} / \mathrm{OM}$} & $7.30 \mathrm{a}$ & $9.74 \mathrm{a}$ & $10.85 \mathrm{a}$ & $13.65 \mathrm{a}$ \\
\hline & \multicolumn{4}{|c|}{ Large fruit yield $\left(M g \cdot h a^{-1}\right)$} \\
\hline Control (PM) & $3.08 \mathrm{c}$ & $4.02 \mathrm{c}$ & $7.51 \mathrm{~b}$ & $4.90 \mathrm{~b}$ \\
\hline MC33 & $3.17 \mathrm{c}$ & $9.21 \mathrm{a}$ & $9.52 \mathrm{ab}$ & $5.80 \mathrm{~b}$ \\
\hline Herbicide/OM & $5.88 \mathrm{~b}$ & $6.59 \mathrm{~b}$ & $8.72 \mathrm{ab}$ & $4.78 \mathrm{~b}$ \\
\hline $\mathrm{PM} / \mathrm{OM}$ & $8.31 \mathrm{a}$ & $10.30 \mathrm{a}$ & $10.66 \mathrm{a}$ & $10.08 \mathrm{a}$ \\
\hline
\end{tabular}

${ }^{\mathrm{z}}$ Control $(\mathrm{PM})=$ plastic mulch alone; MC33 = fumigated with a mixture of methyl bromide $(67 \%)$ and chloropicrin $(33 \%)$ and with plastic mulch; Herbicide/OM = organic mulch treated with herbicides (Dual Magnum ${ }^{\circledR}$ plus Devrinol ${ }^{\circledR}$ ); and $\mathrm{PM} / \mathrm{OM}=$ plastic mulch installed over the organic mulch on raised beds.

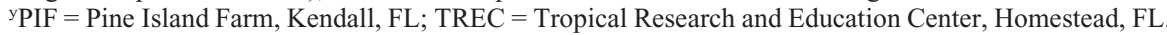
${ }^{x}$ Values within a column followed by the same letter(s) are not significantly different $(P \leq 0.05)$.

Table 4. Total marketable yields $\left(\mathrm{Mg} \cdot \mathrm{ha}^{-1}\right)$ of bell pepper fruits from the first two harvests in 2 years at PIF and TREC sites.

\begin{tabular}{|c|c|c|c|c|}
\hline \multirow[b]{2}{*}{ Treatment ${ }^{z}$} & \multicolumn{2}{|c|}{ PIF site ${ }^{y}$} & \multicolumn{2}{|c|}{ TREC site } \\
\hline & $2004-2005$ & $2005-2006$ & $2006-2007$ & $2007-2008$ \\
\hline & \multicolumn{4}{|c|}{ First harvest $\left(M g \cdot h a^{-1}\right)$} \\
\hline Control (PM) & $0.13 b^{x}$ & $1.30 \mathrm{~b}$ & $2.70 \mathrm{a}$ & $0.04 \mathrm{~b}$ \\
\hline MC33 & $0.54 \mathrm{ab}$ & $4.37 \mathrm{a}$ & $1.74 \mathrm{~b}$ & $0.08 \mathrm{~b}$ \\
\hline Herbicide/OM & $0.82 \mathrm{ab}$ & $2.47 \mathrm{~b}$ & $2.52 \mathrm{ab}$ & $0.04 \mathrm{~b}$ \\
\hline \multirow[t]{2}{*}{$\mathrm{PM} / \mathrm{OM}$} & $1.80 \mathrm{a}$ & $4.61 \mathrm{a}$ & $2.65 \mathrm{a}$ & $0.43 \mathrm{a}$ \\
\hline & \multicolumn{4}{|c|}{ Second harvest $\left(M g \cdot h a^{-1}\right)$} \\
\hline Control (PM) & $0.56 \mathrm{~b}$ & $1.47 \mathrm{c}$ & $5.95 \mathrm{~b}$ & $0.84 \mathrm{~b}$ \\
\hline MC33 & $1.15 \mathrm{ab}$ & $3.29 \mathrm{ab}$ & $10.10 \mathrm{a}$ & $1.68 \mathrm{a}$ \\
\hline Herbicide/OM & $1.02 \mathrm{ab}$ & $2.02 \mathrm{bc}$ & $9.76 \mathrm{ab}$ & $1.15 \mathrm{~b}$ \\
\hline $\mathrm{PM} / \mathrm{OM}$ & $1.23 \mathrm{a}$ & $4.30 \mathrm{a}$ & $11.58 \mathrm{a}$ & $1.58 \mathrm{ab}$ \\
\hline
\end{tabular}

${ }^{2}$ Control $(\mathrm{PM})=$ plastic mulch alone; MC33 = fumigated with a mixture of methyl bromide $(67 \%)$ and chloropicrin $(33 \%)$ and with plastic mulch; Herbicide/OM = organic mulch treated with herbicides (Dual Magnum ${ }^{\circledR}$ plus Devrinol $\left.{ }^{\circledR}\right)$; and $\mathrm{PM} / \mathrm{OM}=$ plastic mulch installed over the organic mulch on raised beds. ${ }^{\mathrm{y}} \mathrm{PIF}=$ Pine Island Farm, Kendall, FL; TREC = Tropical Research and Education Center, Homestead, FL. ${ }^{x}$ Values followed by same letter(s) within a column for various treatments or within a row between 2 years in either the first or second harvest are not significantly different $(P \leq 0.05)$.

Table 5. Yields $\left(\mathrm{Mg} \cdot \mathrm{ha}^{-1}\right)$ of bell pepper extra large fruit from the first two harvests with various treatments in 2 years at PIF and TREC sites.

\begin{tabular}{lcccc}
\hline & \multicolumn{2}{c}{ PIF site $^{\mathrm{y}}$} & \multicolumn{2}{c}{ TREC site } \\
\cline { 2 - 4 } Treatment $^{\mathrm{z}}$ & $2004-2005$ & $2005-2006$ & First harvest $\left(M g \cdot h \mathrm{a}^{-1}\right)$ & $2007-2008$ \\
\hline Control (PM) & $0.13 \mathrm{~b}^{\mathrm{x}}$ & $0.42 \mathrm{~b}$ & $1.57 \mathrm{a}$ & $0.02 \mathrm{~b}$ \\
MC33 & $0.46 \mathrm{~b}$ & $2.16 \mathrm{a}$ & $0.85 \mathrm{~b}$ & $0.06 \mathrm{~b}$ \\
Herbicide/OM & $0.63 \mathrm{ab}$ & $0.95 \mathrm{~b}$ & $1.47 \mathrm{ab}$ & $0.04 \mathrm{~b}$ \\
PM/OM & $1.57 \mathrm{a}$ & $2.34 \mathrm{a}$ & $1.83 \mathrm{a}$ & $0.25 \mathrm{a}$ \\
& & Second harvest $\left(M g \cdot h a^{-1}\right)$ & $0.62 \mathrm{~b}$ \\
Control (PM) & $0.18 \mathrm{~b}$ & $0.56 \mathrm{~b}$ & $0.24 \mathrm{~b}$ & $0.88 \mathrm{a}$ \\
MC33 & $0.64 \mathrm{ab}$ & $1.06 \mathrm{ab}$ & $0.42 \mathrm{ab}$ & $0.68 \mathrm{~b}$ \\
Herbicide/OM & $0.56 \mathrm{ab}$ & $0.57 \mathrm{~b}$ & $0.38 \mathrm{ab}$ & $0.97 \mathrm{a}$ \\
PM/OM & $0.71 \mathrm{a}$ & $1.56 \mathrm{a}$ & $0.54 \mathrm{a}$ & $\mathrm{a}$ \\
\hline
\end{tabular}

${ }^{2}$ Control $(\mathrm{PM})=$ plastic mulch alone; $\mathrm{MC} 33$ = fumigated with a mixture of methyl bromide $(67 \%)$ and chloropicrin (33\%) and with plastic mulch; Herbicide/OM = organic mulch treated with herbicides (Dual Magnum ${ }^{\circledR}$ plus Devrinol ${ }^{\circledR}$ ); and $\mathrm{PM} / \mathrm{OM}=$ plastic mulch installed over the organic mulch on raised beds. yPIF = Pine Island Farm, Kendall, FL; TREC = Tropical Research and Education Center, Homestead, FL. ${ }^{\mathrm{x}}$ Values followed by same letters within a column for various treatments or a row between the 2 years at the same site in either the first or the second harvest are not significantly different $(P \leq 0.05)$.

with the soil (Lal, 2004). However, a rapid decomposition and mineralization of nutrients happened in the next year when the organic mulch had to be incorporated into the soil for land preparation and raised beds reformed. Similar results were found in the previous experiment with different rates of organic mulch on tomatoes; a low rate with 
Table 6. Differences in soil fertility with various treatments at the end of experiments on PIF and TREC sites.

\begin{tabular}{|c|c|c|c|c|c|c|c|c|}
\hline \multirow[b]{2}{*}{ Treatment $^{\mathrm{z}}$} & \multicolumn{4}{|c|}{ PIF site ${ }^{y}$} & \multicolumn{4}{|c|}{ TREC site } \\
\hline & $\begin{array}{l}\text { Organic carbon } \\
\left(\mathrm{g} \cdot \mathrm{kg}^{-1}\right)\end{array}$ & $\begin{array}{c}\text { Nitrogen } \\
\left(\mathrm{g} \cdot \mathrm{kg}^{-1}\right)\end{array}$ & $\begin{array}{l}\text { Phosphorus } \\
\left(\mathrm{g} \cdot \mathrm{kg}^{-1}\right)\end{array}$ & $\begin{array}{c}\mathrm{EC} \\
\left(\mathrm{mS} \cdot \mathrm{cm}^{-1}\right)\end{array}$ & $\begin{array}{l}\text { Organic carbon } \\
\left(\mathrm{g} \cdot \mathrm{kg}^{-1}\right)\end{array}$ & $\begin{array}{c}\text { Nitrogen } \\
\left(\mathrm{g} \cdot \mathrm{kg}^{-1}\right)\end{array}$ & $\begin{array}{l}\text { Phosphorus } \\
\left(\mathrm{mg} \cdot \mathrm{kg}^{-1}\right)\end{array}$ & $\begin{array}{c}\mathrm{EC} \\
\left(\mathrm{mS} \cdot \mathrm{cm}^{-1}\right)\end{array}$ \\
\hline Control (PM) & $13.9 \mathrm{~b}^{\mathrm{x}}$ & $1.3 \mathrm{~b}$ & $0.57 \mathrm{~b}$ & $0.41 \mathrm{~b}$ & $23.1 \mathrm{~b}$ & $2.3 \mathrm{~b}$ & $0.096 \mathrm{~b}$ & $1.61 \mathrm{a}$ \\
\hline MC33 & $15.9 \mathrm{~b}$ & $1.5 \mathrm{~b}$ & $0.71 \mathrm{~b}$ & $0.42 \mathrm{~b}$ & $25.7 \mathrm{~b}$ & $2.4 \mathrm{~b}$ & $0.131 \mathrm{~b}$ & $1.09 \mathrm{~b}$ \\
\hline Herbicide/OM & $36.9 \mathrm{a}$ & $4.2 \mathrm{a}$ & $1.34 \mathrm{a}$ & $0.71 \mathrm{a}$ & $35.8 \mathrm{a}$ & $5.6 \mathrm{a}$ & $0.156 \mathrm{a}$ & $1.12 \mathrm{ab}$ \\
\hline $\mathrm{PM} / \mathrm{OM}$ & $33.5 \mathrm{a}$ & $3.5 \mathrm{a}$ & $1.22 \mathrm{a}$ & $0.70 \mathrm{a}$ & $35.2 \mathrm{a}$ & $4.8 \mathrm{a}$ & $0.139 \mathrm{ab}$ & $2.32 \mathrm{a}$ \\
\hline
\end{tabular}

${ }^{\mathrm{z}}$ Control $(\mathrm{PM})=$ plastic mulch alone; $\mathrm{MC} 33$ = fumigated with a mixture of methyl bromide (67\%) and chloropicrin (33\%) and with plastic mulch; Herbicide/OM = organic mulch treated with herbicides (Dual Magnum ${ }^{\circledR}$ plus Devrinol ${ }^{\circledR}$ ); and PM/OM = plastic mulch installed over the organic mulch on raised beds.

y PIF = Pine Island Farm, Kendall, FL; TREC = Tropical Research and Education Center, Homestead, FL.

${ }^{\mathrm{x}}$ Values followed by same letters within a column for various treatments are not significantly different $(P \leq 0.05)$.

$\mathrm{EC}=$ electrical conductivity.

Table 7. Total costs and returns from different treatments based on average yields and prices.

\begin{tabular}{lcccc}
\hline & \multicolumn{4}{c}{ Treatment } \\
\cline { 2 - 5 } Item & Control & MC33 & Herb/OM & PM/OM \\
\hline Yield (12.7-kg carton) & 1,051 & 1,481 & 1,131 & 1,763 \\
Price per 12.7-kg carton & $\$ 16.81$ & $\$ 16.81$ & $\$ 16.80$ & $\$ 17.21$ \\
Gross Returns (U.S. \$/ha) & $\$ 17,671$ & $\$ 24,893$ & $\$ 18,999$ & $\$ 30,340$ \\
Costs (U.S. \$/ha) & & & & \\
$\quad$ Fumigant & - & $\$ 2,545$ & - & - \\
$\quad$ Compost: purchasing + haul + spread & - & - & $\$ 1,231$ & $\$ 1,231$ \\
$\quad$ Other variable production costs & $\$ 10,448$ & $\$ 10,448$ & $\$ 10,265$ & $\$ 10,448$ \\
$\quad$ Harvesting and marketing costs & $\$ 4,865$ & $\$ 6,852$ & $\$ 5,229$ & $\$ 7,836$ \\
Variable cost & $\$ 15,313$ & $\$ 19,845$ & $\$ 16,725$ & $\$ 19,515$ \\
Fixed cost & $\$ 1,225$ & $\$ 1,225$ & $\$ 1,225$ & $\$ 1,225$ \\
Total costs & $\$ 16,538$ & $\$ 21,070$ & $\$ 17,951$ & $\$ 20,740$ \\
Net returns (U.S. \$/ha) & $\$ 1,133$ & $\$ 3,823$ & $\$ 1,048$ & $\$ 9,600$ \\
Breakeven analysis & & & & $\$ 15.87$ \\
$\quad$ Breakeven price (U.S. \$/ha) & $\$ 15.74$ & $\$ 14.23$ & $\$ 15.87$ & $\$ 11.76$ \\
$\quad$ Breakeven yield (12.7-kg carton) & 983.6 & 1253.6 & 1068.6 & 1205.2 \\
$\quad$ Margin of safety (\%) & 6 & 15 & 6 & 32 \\
\hline
\end{tabular}

${ }^{2}$ The tomato price was based on Atlanta Terminal market prices during 2004-2008 for extra large, large, and medium-sized green bell peppers obtained from the USDA's Agricultural Marketing Service (http://marketnews.usda.gov/portal/fv) and averaged over the harvest season of November through June. For detailed calculations on each item, please refer to the respective section of the text.

an extra year of application had similar yield responses as compared with a high rate (Wang et al., 2009).

Among all the treatments, $\mathrm{PM} / \mathrm{OM}$ seems to help create a favorable environment in the root zone with an artificial organic layer. The layer might improve soil physiochemical properties such as water-holding capacity, bulk density, and available nutrient supply through slow decomposition of the compost. Furthermore, the plastic mulch on top of the organic mulch can effectively suppress most species of weeds throughout the growth season and reduce water loss through evaporation considerably. Therefore, generally a higher yield was obtained by the combination of organic and plastic mulches. Unfortunately, the total marketable yields in the herbicide/OM treatment were unexpectedly lower than those in the PM/OM treatment. This can be seen in 2005-2006 at PIF and 2007-2008 at TREC or even lower than the yield with MC33, e.g., 2005-2006 at PIF (Table 3). The fluctuation in soil moisture, root zone temperature, and nutrient leaching, and so on, with the treatment of herbicide/ OM might cause yield losses as compared with the treatment of $\mathrm{PM} / \mathrm{OM}$ under some circumstances.

Pepper marketable yields and quality from early harvests. The demand for winter fresh market vegetables such as bell peppers is especially strong during the period between Thanksgiving and the New Year. Most growers prefer to grow vegetables starting in October rather than September to avoid possible damage by tropical storms and hurricanes in the subtropical region such as in south Florida. Under such circumstances, early harvests, especially the first two harvests with quality peppers, tend to be particularly profitable meeting the market demand for winter fresh vegetables.

The total marketable yields from the first harvest were in a rank of $\mathrm{PM} / \mathrm{OM} \geq$ herbicide/ $\mathrm{OM}=\mathrm{MC} 33 \geq$ control at PIF in 2004-2005; $\mathrm{PM} / \mathrm{OM}=\mathrm{MC} 33>$ herbicide $/ \mathrm{OM}=$ control in 2005-2006; $\mathrm{PM} / \mathrm{OM}=$ control $\geq$ herbicide/ $\mathrm{OM} \geq \mathrm{MC} 33$ at TREC in 2006-2007; and $\mathrm{PM} / \mathrm{OM}>$ herbicide $/ \mathrm{OM}=\mathrm{MC} 33=$ control in 2007-2008 (Table 4). The marketable yields from the second harvest showed the same pattern as in the first harvest for PIF in 2004-2005; PM/OM $\geq$ MC33 $\geq$ herbicide/ $\mathrm{OM} \geq$ control in 2005-2006; $\mathrm{PM} / \mathrm{OM}=$ MC33 $\geq$ herbicide/OM $\geq$ control at TREC in 2006-2007; and $\mathrm{MC} 33 \geq \mathrm{PM} / \mathrm{OM} \geq$ herbicide/OM = control in 2007-2008 (Table 4). In general, relatively higher yields from the first two harvests were obtained with $\mathrm{PM} / \mathrm{OM}$ treatment compared with the control except the first harvest in 2006-2007 and the second harvest in 2007-2008 at TREC. The results indicated that, in general, the combination of plastic mulch with organic mulch in the vegetable production system may provide more benefits during the favorable period to meet the market demand.
Besides the marketable yield, fruit size as a main quality attribute for bell peppers is important because consumers usually prefer extra large fruits. Fruit size is also an important indicator for the early harvests. The extra large fruit yields (Table 5) from the first two harvests had a similar trend as the total marketable yields with some exceptions. The $\mathrm{PM} / \mathrm{OM}$ treatment produced greater extra large fruit yields in the first two harvests in most cases as compared with other treatments such as PM alone except the first harvest in 2006-2007 at TREC.

After 2-year experiments on each site, the fundamental variables related to the soil fertility were improved considerably with $\mathrm{PM} / \mathrm{OM}$ and herbicide/OM. Some exceptions existed such as phosphorus content with PM/ $\mathrm{OM}$ and electrical conductivity with herbicide/OM at TREC (Table 6). The soil fertility improvement with organic mulch application combined with favorable alteration in soil physicochemical properties might explain the substantial increases in pepper yields and quality with the PM/OM treatment.

Economic benefits from various treatments. Based on total costs and income returns with various treatments (Table 7), the $\mathrm{PM} / \mathrm{OM}$ treatment was found to be the most profitable of the four treatments with average net returns of $\$ 9600 /$ ha. The least profitable treatment was herbicide/OM with net returns of $\$ 1048 / \mathrm{ha}$. Of interest is that compared with the more commonly used MC33 treatment, the net return generated from the $\mathrm{PM} / \mathrm{OM}$ system was $\$ 5777 /$ ha higher or an increase in earnings of $\approx 151 \%$. Given the need to adopt alternatives to methyl bromide, application of the readily available compost seems encouraging. The similar production system, based on biological soil disinfestations of pests and pathogens, has been reported in Europe (Blok et al., 2007; van der Hulst, 2006) and Japan (Momma, 2008).

The breakeven analysis revealed that the $\mathrm{PM} / \mathrm{OM}$ treatment generated the highest breakeven revenue and lowest breakeven price of $\$ 11.76$ per carton compared with $\$ 14.23, \$ 15.74$, and $\$ 15.87$ per carton for the $\mathrm{MC} 33$, control, and herbicide/OM treatments, respectively. Looked at from a slightly different perspective, the safety margins were as high as $32 \%$ for PM/OM but only $6 \%$ for herbicide/OM and control treatments, respectively (Table 7). Based on the criterion defined as a $20 \%$ safety margin, only the PM/ $\mathrm{OM}$ practice can meet this requirement. 
Therefore, growers would likely adopt the $\mathrm{PM} / \mathrm{OM}$ approach and obtain more profits than the other approaches, including the MC33 practice, even as a critical use exemption. Growers most certainly would not adopt the plastic mulch alone or the herbicide/OM treatment, al though the costs of inputs of these latter two options were lower than those of the PM/OM and MC33 systems.

\section{Conclusions}

Compost applied as an organic mulch for bell pepper production can concomitantly improve the marketable yields and quality of bell pepper fruit as a result of improvements in soil fertility in both sandy and gravelly loam soils. Plastic mulch installed over an organic mulch of compost applied to the soil surface of the raised beds (PM/OM) produced the greatest marketable yields with high yields of extra large and large fruits. It also can provide quality pepper fruits to the winter fresh market to meet customer demands on time. The combination of organic with plastic mulches showed the greatest economic profits compared with the other approaches, displayed the lowest breakeven price, and the highest safety margin. It implies preferences of vegetable growers adopting the system and it has demonstrated great potential in the development of sustainable agriculture and organic farming.

\section{Literature Cited}

Beirlein, J., K. Schneeberger, and D. Osburn. 1995. Principles of agribusiness management. 2nd Ed. Waveland Press Inc., Prospect Heights, IL.

Beloso, M.C., M.C. Villar, A. Cabaneiro, N.M. Carballas, S.J. Gonzalez-Prieto, and T. Carballas. 1993. Carbon and nitrogen mineralization in an acid soil fertilized with composted urban refuses. Bioresour. Technol. 45:123-129.

Blok, W.J., T.C.M. Coenen, A.J. Termorshuizen, and J.G. Lamers. 2007. The potential of biological soil disinfestation to manage fusarium foot and root rot in asparagus. Acta Hort. 776:135-144.

Bryan, H.H., L.J. Ramos, M. Codallo, and J.W. Scott. 1997. Effects of soil fumigation, compost, and non-fumigation on the yield, fruit quality, disease incidence, and other variables of tomato cultivars. Proc. Fla. State Hort. Soc. 110:269-272.

Cambardella, C.A., T.L. Richard, and A. Russell. 2003. Compost mineralization in soil as a function of composting process conditions. Eur. J. Soil Biol. 39:117-127.

Chellemi, D.O., D.J. Mitchell, and A.W. Barkdol. 1992. Effect of composted organic amendments on the incidence of bacterial wilt to tomato. Proc. Fla. State Hort. Soc. 105:364-366.

Clark, G.A., C.D. Stanley, and D.N. Maynard. 1995. Municipal solid waste compost in irri- gated vegetable production. Soil Crop Sci. Soc. Fla. Proc. 54:49-53.

Cortellini, L., G. Toderi, G. Balsoni, and A. Nassissi. 1996. Effects on the content of organic matter, nitrogen, phosphorus and heavy metals in soil and plants after application of compost and sewage sludge, p. 457-468. In: De Bertoldi, M., P. Sequi, B. Lemmes and T. Papi (eds.). The science of composting. Blackie Academic \& Professional, Chapman \& Hall, London, UK.

Duggan, J.C. 1973. Utilization of municipal refuse compost: I. Field-scale compost demonstrations. Compost Sci. Util. 14:24-25.

Florida Department of Environmental Protection. 2007. Recycling - 2005 solid waste annual report. 20 Aug. 2009. <http://www.dep.state.fl.us/waste/ categories/recycling/pages/05_data.htm $>$.

Goldstein, N. 1997. The state of garbage in America. Biocycle 38:60-67.

Heiri, O., A.F. Lotter, and G. Lemcke. 2001. Loss on ignition as a method for estimating organic and carbonate content in sediments: Reproducibility and comparability of results. J. Paleolimnol. 25:101-110.

Lal, R. 2004. Soil carbon sequestration to mitigate climate change. Geoderma 123:1-22.

Li, Y., P.J. Stoffella, and H.H. Bryan. 2000. Management of organic amendments in vegetable crop production systems in Florida. Soil Crop Sci. Soc. Fla. Proc. 59:17-21.

Mannion, C.M., B. Schaffer, M. Ozores-Hampton, H.H. Bryan, and R. McSorley. 1994. Nematode population dynamics in municipal solid waste amended soil during tomato and squash cultivation. Nematropica 24:17-24.

Maynard, A.A. 1995. Increasing tomato yields with MSW compost. Biocycle 36:104-106.

Momma, N. 2008. Biological soil disinfestation (BSD) of soilborne pathogens and its possible mechanisms. Jpn. Agr. Res. Q. 42:712.

Olson, S.M., E.H. Simonne, W.M. Stall, K.L. Pernezny, S.E. Webb, T.G. Taylor, S.A. Smith, and D.M. Parmenter. 2006. Pepper production in Florida, p. 331-343. In: Olson, S.M. and E. Simonne (eds.). Vegetable production handbook for Florida 2006-2007. Vance Publishing, Lincolnshire, IL.

Ozores-Hampton, M., E. Hanlon, H. Bryan, and B. Schaffer. 1994. Cadmium, copper, lead, nickel and zinc concentrations in tomato and squash grown in MSW compost-amended calcareous soil. Compost Sci. Util. 5:40-45.

Paino, V., P. Peillex, O. Montlahuc, A. Cambon, and J.P. Bianchini. 1996. Municipal tropical compost: Effects on crops and soil properties. Compost Sci. Util. 4:62-69.

Rothwell, D.F. and C.C. Hortenstine. 1969. Composted municipal refuse: Its effects on carbon dioxide, nitrate, fungi, and bacteria in Arredondo fine sand. Agron. J. 61:837-840.

SAS Institute. 2004. SAS/STAT user's guide. Version 9.1.3. SAS Institute, Inc., Cary, NC.

Serria-Wittling, C., S. Houot, and E. Barriuso. 1996. Modification of soil water retention and biological properties by municipal solid waste compost. Compost Sci. Util. 4:44-52.
Slivka, D.C., T.A. McClure, A. Buhr, and R.A. Albrecht. 1992. Compost: United States supply and demand potential. Biomass Bioenergy 3:281-299.

Smith, S.A. 2004. Enterprise budgets for agricultural commodities in Florida: Vegetables, 1999 2004. 25 Aug. 2009. <www.agbuscenter.ifas.ufl. edu $>$.

South Florida Water Management District. 2007. Executive summary 2007 south Florida environmental report. 20 Aug. 2009. <http://sfwmd. gov>.

Stoffella, P.J. and Y. Li. 2001. Organic waste compost utilization in vegetable crop production systems. Proc. Interamerican Soc. Tropical Hort. 43:30-32.

Turner, M.S., G.A. Clark, C.D. Stanley, and A.G. Smajstrla. 1994. Physical characteristics of sandy soil amended with municipal solid waste compost. Proc. Soil Crop Sci. Soc. Fla. 53:2426.

U.S. Department of Agriculture. 1989. United States standards for grades of sweet peppers. Published by USDA-Agricultural Marketing Service.

U.S. Department of State. 2006. United States nomination for critical use exemptions from 2008 phaseout of methyl bromide. 25 Aug. 2009. $<$ http://www.epa.gov/ozone/mbr/2008nomination. $\mathrm{html}>$.

U.S. Environmental Protection Agency. 1990. Methods for chemical analysis of water and wastes. Environ. Monit. Support Lab., Cincinnati, $\mathrm{OH}$.

U.S. Environmental Protection Agency. 1993. Summary of markets for compost. USEPA report 530SW90073B. National Service Center, Environ. Publ., Cincinnati, $\mathrm{OH}$.

U.S. Environmental Protection Agency. 1994. Composting of yard trimmings and municipal solid waste. USEPA report 530R940031. Dept. of Commerce, National Technical Information Service, Springfield, VA.

van der Hulst, J. 2006. Biological soil disinfestation. Fruit and Vegetable Technology 3.1. 20 Aug. 2009. <http://www.hortiworld.nl>.

Wagner, S.C., D.J. Hanson, A. Olness, and W.D. Voorhess. 1998. A volumetric inorganic carbon analysis system. Soil Sci. Soc. Amer. J. 62: 690-693.

Wang, Q., H.H. Bryan, W. Klassen, Y. Li, M. Codallo, and A. Abdul-Baki. 2002. Improved tomato production with summer cover crops and reduced irrigation rates. Proc. Fla. State Hort. Soc. 115:202-207.

Wang, Q., W. Klassen, Y. Li, and M. Codallo. 2009. Cover crops and organic mulch to improve tomato yields and soil fertility. Agron. J. 101:345-351.

Wang, Q., Y. Li, and W. Klassen. 2006. Summer cover crops and soil amendments to improve growth and nutrient uptake of okra. HortTechnology 16:328-338.

Wang, Q., Y. Li, and W. Klassen. 2007. Influence of cover crops and soil amendments on okra (Abelmoschus esculentus L.) production and soil nematodes. Renew. Agr. Food Syst. 22: $41-53$. 